\title{
Igorots in the Blogosphere: Claiming Spaces, Re-constructing Identities
}

LIEZEL C. LONGBOAN, Cardiff University

\begin{abstract}
Indigenous peoples in the Philippines have rarely been covered by the mainstream media, despite comprising 20 percent of the country's total population. Lacking access to the media due to various constraints, they have had limited opportunities to create content themselves. But the emergence of the Internet, particularly blogs, is now providing members of indigenous communities with the much-needed space for self-expression. More particularly, several indigenous groups in North Luzon, collectively known as Igorots, are using blogs more extensively to re-construct and re-present their ethnic identity in cyberspace. For this paper, I shall describe how a group of Igorot bloggers protested about a controversial Igorot statue and how this eventually led to its removal.
\end{abstract}

\section{KEYWORDS}

Ethnic identity; new media; Internet; blogs; pluralism

\section{Background}

In looking at ethnic identity construction within the context of blogging, I aim to analyse how marginalized groups, such as indigenous peoples, are creating discourses about themselves on the Internet. While most communication and media research relating to Igorots in the North Philippines have focused on how they have been represented by the broadcast media, this study situates modern-day Igorots as active agents rather than passive subjects of representation as they appropriate the Internet to negotiate and reconstruct their ethnic identity.

The Philippines is a multi-ethnic society, having at least 77 ethno-linguistic groups (NCCA 2007) and 171 living languages (Gordon, et al. 2005). The people who speak these languages similarly have their own distinct cultures (Asian Development Bank 2002: 25). Filipinos' conversion to Christianity during the Spanish colonial period and America's subsequent colonial policy significantly shaped how the diverse groups in the country would eventually be governed (Finin 2005: 40). Consequently, 'some groups define[d] themselves as distinct from a perceived majority and their state institutions' (Hirtz 2003: 895).

That the Spaniards called lowland Filipinos 'indios' apparently gave Americans the impression that Filipinos were like American 'Indians'. This has led the American government to use the same policy they have used with North American Indians toward Filipinos (Finin 2005: 25). After the fierce fighting that took place during the PhilippineAmerican war, the US created the Philippine Commission in 1902, which would oversee the administration of their new colony. The year after that, the commission set up the Bureau of Non-Christian Tribes headed by David P. Barrows, an anthropologist trained at the University of Chicago (ibid: 28). He was responsible for organizing the 1903 census which 
formalized how the country's different socio-linguistic groups would later on be categorized, dividing residents into two groups: "Christian or civilized tribes" and "Non-Christian, or wild tribes"” (ibid).

The most influential American who set in place the administrative policies for dealing with indigenous minorities was Dean Worcester, who served as the country's interior secretary for 13 years (Hirtz 2003: 895). A zoologist, Worcester made extensive trips to the mountains and classified tribes based on their 'physical characteristics and appearance' (Finin 2005: 35). He guided American policy in delineating one province from another, establishing the US colonial hold among the Igorots (ibid: 36 ).

\section{Philippine Indigenous Peoples}

Based on extrapolated data, there are roughly 18 million indigenous people in the Philippines, making up 20 percent of the country's total population (ADB 2002: 25). They are composed of 110 ethno-linguistic groups living in various parts of the country. According to the National Commission on Indigenous Peoples (NCIP), the majority of them belong to the poorest regions, due to their 'centuries-long isolation' (2003).

The NCIP, the lead government agency mandated to protect the interest of indigenous peoples, defines indigenous peoples as

(A) group of people or homogenous societies identified by self ascription and ascription by others, who have continuously lived as an organized community or communally bounded and defined territory, and who have, under claims of ownership since time immemorial, occupied, possessed and utilized such territories sharing common bonds of language, customs, traditions and other distinctive cultural traits, or who have through resistance to political, social and cultural inroads of colonization, non-indigenous religions and cultures became historically differentiated from the majority Filipinos.

(NCIP 2003)

In the North Philippines, there are several indigenous groups collectively known as Igorots. Estimated at 1.2 million, they have occupied their ancestral lands since time immemorial and have kept their 'traditions, distinct languages, and socio-political systems' over the centuries (ADB 2002: 25). The failure of the Spanish colonial regime to put them under their control, that is, to Christianize them and to penetrate their land, has made them a 'minority' as compared to the colonized Filipino 'majority'. The Igorots were classified as 'uncivilized tribes' by the Bureau of Non-Christian Tribes established by the Americans in 1901 (Forbes 1928 in Finin 2006: 29).

Scholars have offered various explanations for the origin of the term 'Igorot', which is not part of any of the languages within the region. According to Filipino anthropologist June Prill-Brett, it may have been derived from the Ilocano word 'gerret', which means to cut off or slice, which can then be traced to the headhunting past of the Igorots (ibid: 11). While it is a word that is foreign to indigenous groups, the word Igorot carries to this day a negative connotation. Thus, a few groups prefer to be identified by their specific ethnic groups, such as the Ifugaos and Kalingas, rather than the more inclusive, albeit problematic, name Igorots 
(Rabia, forthcoming).

In 1986, the Philippine government created the Cordillera Autonomous Region, as it recognized the Igorots' distinct history and culture. The region comprises six provinces and one city, namely, Benguet, Ifugao, Mountain Province, Apayao, Kalinga, Abra, and Baguio City. Within each of these provinces are several ethno-linguistic groups with their own particular language, customs and traditions. The major indigenous groups in the region are the Ibalois, Kankana-eys, Bontoks, Applais, Ifugaos, Kalingas, Isnegs and Tingguians. Igorots are the third largest indigenous group in the Philippines (NCIP 2003) and belong to one of the poorest regions in the country; the poverty incidence stands at 28.8 percent as of 2006 (NSCB 2006).

\section{The Philippine Media: Free But Fragile}

Broadly, the development of the Philippine media was largely moulded by the Filipinos' fight for independence against the Spanish and American colonial governments. Thus, early nationalists exposed the abuses of the Spaniards in their writings in Philippine newspapers and later on as propagandists in Europe (Braid \& Tuazon 1999; Coronel 2001), serving as the country's first investigative journalists. With the coming of the Americans, Filipino journalists had to face censorship and imprisonment for criticizing the abuses of the colonial government (Braid \& Tuazon 2006: 296). The stifling of the Filipinos' freedom of expression as colonial subjects from the 16th century until the early 20th century perhaps explains the strong advocacy for a free media in the country. Although Spain was the first to introduce the press system in the country, it would be America who would leave a pervasive influence in the direction of Philippine politics and media, even after the country regained its independence on 4 July 1946 (Coronel 2001).

Often described as the most free in Asia (Braid 1999: 299; Coronel 2001), the Philippine media has been beset by lingering and complex problems which consequently impinge on its effectiveness as a purveyor of information. However, most studies and articles on Philippine media and communication focus on media structures and functions as they influence content and production, often taking for granted the role of audiences in the shaping of the country's media.

A key problem, often identified, is the issue of concentrated media ownership among wealthy families who use the media to promote their various business and political interests. At the time the Philippines won back its independence in 1946, owners of the country's national dailies belonged to political clans whilst at the same time running large businesses from shipping to insurance, real estate to sugar plantations, airlines to soft drinks (Pineda-Ofreneo 1984: 69-73, 171; Coronel 2001: 113; Braid \& Tuazon 1999: 300). This pattern would continue up to this day, when ownership of most national newspapers and broadcast stations is in the hands of a few families who are at the forefront of leading industries and are linked with powerful political clans. At present, the Lopez family owns the largest media company in the country - encompassing TV and radio stations, a recording studio, a film production outfit, and a publishing firm. Apart from this, they are also a major supplier of electricity, water and telephone services; consequently, issues that affect their businesses are reported with caution by the media network (Coronel 2001: 120). 
This situation may be partly to blame for the homogeneous content observable in both the print and broadcast media. In 2004, a study conducted by the Center for Media Freedom and Responsibility found out that the mainstream media primarily focused on stories that were taking place in Metro Manila, the country's capital (Khan 2005: 30). Content analysis of 11 national dailies in August 2004 showed that most (79.54 percent) of the news reports covered Metro Manila and that a negligible percentage (3.59) were devoted to religious, cultural and ethnic minority groups (ibid). A related study showed that the broadcast media is plagued by the same problem faced by the print media (Coronel 2005).

In the print media, such homogeneity may perhaps be explained by the study's findings that the country's seven broadsheets did not have a hiring policy 'that favour[ed] minorities even when covering issues that concern minority groups' (Khan 2005: 30). The absence of such policy is merely a reflection of most editors' view that bringing minorities into the newsroom will not in any way influence the content of the newspaper (ibid).

For the broadcast media, the high cost of putting up television stations, profit-making, and concentrated media power between only two television networks compound to exclude '...news issues, concerns, and voices that will not sell, that have no commercial value for the companies that run television' (Coronel 2005: 27). Consequently, news on television primarily addresses urban audiences, keeping out issues affecting marginalized groups, which includes indigenous peoples (ibid). One television executive has even admitted that they tailor their programs to suit Metro Manila audiences because 'Your revenues are not in the provinces. They are here in Metro Manila' (Rimban 1999: 5).

Another critical issue is the lack of regulations with regard to media practice (Coronel 2005: 118). Generally, media professionals perceive any government policy relating to media regulation as a possible threat to free speech. This aversion to media regulation perhaps finds its roots in the country's grim experience during the Marcos dictatorship from 1965 to 1986. During those years, there emerged an 'establishment' press and an 'alternative' press, the former being cronies and supporters of Marcos and the latter being independent journalists critical of his administration (Braid \& Tuazon 1999: 309-310). These activist-journalists were mainly responsible for informing the public as to what was actually happening in the country. Notably, it was women journalists who were at the forefront of the alternative press (ibid) during what is often described as one of the darkest moments in Philippine history.

In 1986, a popular uprising led by the Roman Catholic Church with the aid of the media ended the dictatorship, paving the way for the writing of a new constitution that enshrines a more liberal provision on free expression under its Bill of Rights. However, it was observed that the end of the Marcos regime and the return of democracy did not facilitate the necessary change in the structures of society, particularly the structure of media ownership (Doronila 1987: 8). The nature of the media as big business is the primary reason why the marginalized sectors are not covered in the news (ibid: 9). More succinctly, Doronila argued that the media is more interested in working within existing political and economic structures 'rather than on changing the system or the rules of the game' (ibid). His observation perhaps explains why rampant bribe-taking and collusion between journalists and media owners with politicians have been documented, especially during the 1992, 1998 and 2004 presidential elections (Hofilena 2004; Coronel 2005). Whilst members of the media played a key role in toppling Marcos and restoring democracy in the Philippines, they have also contributed to perpetuating its skewed socio-political conditions. 


\section{Philippine Indigenous Media}

Due to their socio-economic marginalization, the majority of indigenous groups in the Philippines have had limited opportunities to access and create media content. Apparently, it is only members of indigenous groups in the Cordillera region in North Luzon who have successfully published their own provincial and regional newspapers.

Within the last one hundred years, early writings about Igorots have been made by 'foreigners or outsiders' (Fong 2005: 3-4), particularly colonial officials, foreign anthropologists, and foreign Catholic and Anglican missionaries. In recent years, representations by the Philippine mainstream media (ibid) have contributed to the existing 'regime of truth' about Igorots. Despite their considerable number, Igorots are seldom covered by the media, and are often represented in a stereotypical manner (Zapata 2006).

The remarkable efforts by American colonial officials to develop the far-flung but apparently mineral-rich areas of the country, including the mountains of Benguet, became the subject of a controversial editorial in the nationalist Filipino-owned Spanish language newspaper, $E l$ Renacimiento (Ordoñez 2007). On 30 October 1908, Fidel Reyes wrote an editorial entitled 'Aves de Rapiña' (Birds of Prey), parts of which follow:

There are men who besides being eagles, have the characteristics of the vulture, the owl, and the vampire. Ascending the mountains of Benguet to classify and measure the skulls of the Igorots and study and civilize them, and to espy in his flight, with the eyes of the bird of prey, where lie the large deposits of gold - the prey concealed within the lonely mountains - to appreciate them for himself afterwards, thanks to the legal facilities made and unmade at will, but always for his own benefit.

(Ordoñez 2007)

Although no names were mentioned, Dean Worcester, Secretary of the Interior and social planner of the Cordillera region, felt he was the one being referred to and filed a case for libel. Reyes was eventually acquitted, but his editor Teodoro Kalaw, and the publisher, Martin Ocampo, were found guilty of the crime (ibid). 'Aves de Rapiña' appears to be the earliest known journalistic piece by the mainstream national press that mentions the Igorots.

The socio-economic changes taking place during the early years of the American occupation have significantly influenced the development of the media in the region. As early as 1911, Baguio had its first newspaper, The Baguio News (ibid). Benguet's economic prosperity brought about by mining and tourism led the country's leading business newspaper, Manila Bulletin, to begin publishing the Baguio Bulletin as a weekly supplement on 21 November 1930 (Finin 2005: 305).

On 28 April 1947, a group of 13 Ibaloys and Ilocanos published the Baguio Midland Courier (ibid), the longest-running local newspaper in the Philippines and apparently the first indigenous newspaper in the country. At the helm of this ambitious project is Sinai Hamada, the son of a landed Ibaloy mother from Benguet and a Japanese engineer father who immigrated to the Philippines during the early American period (Macansantos 2004). The newspaper has played a crucial role in chronicling the major events taking place in the highlands and, more importantly, in serving as an avenue for Igorots to discuss issues particular to them as a group. For a few months in 1953, Igorots wrote endless letters to the 
editor in protest at the then presidential candidate Carlos Romulo's claims in his book Mother America that 'the Igorot is not Filipino' (Finin 2005: 181-182). Interestingly, the paper was later requested by former President Marcos not to publish stories critical of the proposed multi-million Chico River hydroelectric dam project that threatened to inundate hectares of ancestral lands within the Cordillera (ibid: 246).

At present, there are five weekly newspapers published by Igorots in the Cordillera region. These are the Baguio Midland Courier, owned by the Hamada family of Benguet, Cordillera Today, published by former Governor Raul Molintas of Benguet, Northern Philippine Times, owned and edited by Alfred Dizon from Mountain Province, Zigzag, owned by Antonio Pekas, from Mountain Province, and, lastly, High Plains Journal, published by Victor Luacan, again from Mountain Province. These newspapers are circulated in the region's six provinces and one city. Meanwhile, the provincial governments of Mountain Province and Ifugao also maintain their own newspapers. Being local newspapers, they cater to a limited audience within their geographic boundaries.

Personal observations and anecdotal evidence show that, except for some towns in Benguet which are near Baguio City, both local and national newspapers reach most towns in the region in the afternoon of the day they have been published. The seats of municipal and provincial governments are the first to obtain copies of newspapers, being the main destination of buses and other public transportation such as jeepneys and vans. These towns are also where most public transport is stationed. In the more remote areas where roads conditions are worse than those near the capital, newspapers are said to be delivered the following day. In these communities, newspapers remain an expensive commodity and are often shared between households. But with the advent of broadband Internet over the last few years, more people in these far-flung communities are gaining access to news and information that would normally be inaccessible to them.

Among the five local newspapers, only the Baguio Midland Courier and Northern Philippine Times are accessible online: the former has its own website (http://www.baguiomidlandcourier.com.ph) while the latter uses Blogspot (http://northphiltimes.blogspot.com/) to post its stories. The Midland covers only the Cordillera region, but Northern Philippine Times has a broader reach, reporting on the Ilocos region, Cagayan, and Central Luzon areas. Meanwhile, there are also other news sites such as Mountainprovince.net, kalingatambayan.com, and abrenian.com, which provide more local news from their respective provinces. While Mountainprovince.net and abrenian.com have their own contributors, kalingatamabayan.com uses news feeds from the provincial office of the Philippine Information Agency, a government office primarily involved in communication and information campaigns. All three provide a forum where members can participate in discussions.

The liberalized telecommunications policies in the country and strong competition among providers have helped bring media technology to provinces within the Cordillera region (Mendes, et. al. 2007: 23). There are now several Internet cafes and cable television services in a number of towns all over the region, enabling the public to access news and information more quickly than ever before. 


\section{New Media and Philippine Society}

As of 2004, the International Telecommunications Unit (ITU) pegged the personal computer (PC) penetration rate in the Philippines at ' 4.5 for every 100 population' (Astrologo 2006). The country ranked fifth in Southeast Asia, behind Singapore (62.2 per 100 population), Malaysia (19.16), Brunei Darussalam (8.47) and Thailand (6). In terms of Internet use, the ITU reported that, in the same period, there were only 5.32 users for every 100 persons, comparably lower than those of Iran (7.88) and Zimbabwe (6.90) (ibid). But country data on actual Internet use among individuals and households is limited. The only source of data is the National Statistics Office (NSO), through its Functional Literacy, Education and Mass Media Survey (FLEMMS), aimed to gather information on the population's literacy, educational and skills qualifications and exposure to the mass media (ibid: 3; NSO 2003). Based on the latest FLEMMS survey conducted in 2003

the Internet is a source of knowledge and information for $20 \%$ of the country's population 6 years old and over or 13.8 million Pinoys. However, only $7.4 \%$ of them access the Internet for information everyday'

(ibid)

Internet use is also influenced by location, as a study revealed that 70 percent of users are in Metro Manila while the remaining 30 percent are in the provinces (Lallana, et al. 1999: 16 in Sy 2001: 302).

Due perhaps to their relative affordability, mobile phones are the most accessible form of new technology to Filipinos, 30.4 percent of whom live below the poverty line (NSCB 2006). Despite the country's seemingly low PC penetration rate and Internet usage, the Philippines is considered the texting capital of the world (Celdran 2002; Braid \& Tuazon 1999; Thomson 1999 in Sy 2001:300; Wireless Intelligence 2007 in Mendes, et al. 2007: 8), accounting for some ten percent of all SMS messages sent around the world' in 2002 (Astrologo 2006: 300).

Admittedly, information technology has become integral to Filipino life; one cannot analyse the social processes going on in the country without taking it into consideration (Sy 2001: 300). The Internet 'makes possible for Filipinos of diverse ethno-linguistic origins to form virtual communities giving less consideration to Filipino loyalties than to ethno-linguistic and regional groupings - loyalties that are highly enforceable in the geo-political barangay setting (ibid: 298). However, this observation needs to be qualified as the study only described one example. The emergence of online Filipino communities that go beyond regional boundaries may be true only if the issues affect diverse groups of people and are not defined by geography or culture.

Focusing on the power of short message service (SMS) or 'texting', Celdran (2002) explained how a large number of Filipino 'texters' converged on 16 January 2001 at the Epifanio delos Santos Avenue (EDSA) to demand for the resignation of former President Joseph Estrada's. The event became known as EDSA 2, another popular uprising similar to EDSA 1 in 1986, which was led by a network of average, ordinary citizens and not by the Roman Catholic Church or the opposition (ibid). However, the use of mobile phones during this particular period has been framed along class lines, with the protesters described as 'technologically savvy and politically sophisticated...' (Rafael 2003: 423). 
Weblogs, or 'blogs' as they are more popularly known, are still an unexplored area of research in the Philippines (Pabico 2005). However, blogs are increasingly being studied by media and communication researchers worldwide, due to their dynamic qualities. Woodly (2007: 115) mentions that 'As a discursive form blogs stand between traditional print and broadcast media and small group discussion'. It has also been described as 'a cross between a column and a talk radio' (Khan 2006).

At their core, weblogs are pages consisting of several posts or distinct chunks of information per page, usually arranged in reverse chronology from the most recent post at the top of the page to the oldest post at the bottom.

(Bausch, et al. 2002: 7).

They may be authored by one person, by a group of persons or by a large community of individuals (ibid). In terms of content, single-author blogs 'usually take on a personal tone' and 'frequently offer a refreshing, personal, non-commercial tone absent from much of the typical content found on the Web' (ibid: 5)

Data from Blogwise in 2005 showed that there were 1,265 blogs in the Philippines, placing it tenth worldwide in terms of having the most blogs (Pabico 2005). Informal research conducted by a US-based Filipina blogger known as 'The $\mathrm{Ca}$ t' (cathcath.com in Pabico 2005) revealed that 51 percent of Filipino-owned blogs are online diaries. This was followed by entertainment (14 percent), politics and news (12 percent), and technology (10 percent) (ibid). Looking at 120 blogs, The $\mathrm{Ca} \mathrm{t}$ found that, for Philippine-based blogs, males outnumbered females, while, for overseas blogs, female bloggers made up 70 percent of the total (cathcath.com). She also concluded that the content of blogs were influenced by age and civil status of the blogger, with younger bloggers writing about school and relationships, while older bloggers wrote on more diverse topics (ibid).

The year 2005 apparently signalled the flourishing of blogging in the Philippines fuelled by 'Gloriagate' (Olarte 2005), the scandal brought about by alleged telephone calls made by President Gloria Macapagal-Arroyo requesting elections commissioner Virgilio Garcillano pad her votes during the 2004 presidential election. Several journalists, one local newspaper and one media watchdog put up their own blogs at the height of the controversy, while the institutional blog run by Philippine Center for Investigative Journalism (PCIJ) got swamped with 'download requests unprecedented in its existence' (Pabico 2005). Journalists recognize that blogs have technical features that facilitate a high degree of journalistic practice, among them interactivity with readers and immediacy of publication (ibid).

\section{Blogs as Socio-Cultural Spaces}

Within the last few years, the Internet, through blogs and forums, has been providing Igorots from the Cordillera region in North Luzon space to create original content. In undertaking this research, I am primarily interested in describing the discourses that are present in the blog posts of selected Igorot bloggers as they relate to their ethnic identity. For this paper, I will highlight how a group of Igorot bloggers networked to address issues relating to their ethnicity. But before proceeding, three limitations in conducting this research need to be mentioned. First, because of the stigma still attached to the word 'Igorot', there are still people who belong to this indigenous group who do not want to be called or to be identified as such. Thus, they may choose not to reveal their ethnicity in their blogs, although they may 
write about their particular indigenous culture. Second, it is also highly probable that some Igorots who do acknowledge their ethnicity are writing about themes other than their ethnic roots, culture or hometowns. Again, this would prevent me from finding their sites through a Google search or through links by other bloggers. Third, I have mainly relied on Google searches, the blog roll of Bill Bilig (http://igorotblogger.blogspot.com) and the blog roll of other bloggers in seeking out Igorot blogs.

As mentioned earlier, 'Igorot' is a collective term used to refer to indigenous groups in North Luzon. Thus, Igorot blogs refer to those blogs owned and maintained by individuals who belong to any of the indigenous groups in the Cordillera Administrative Region and the province of Nueva Vizcaya. I was able to ascertain them as such because the bloggers have identified their ethnicity either in their blog profiles or in some of their posts. As of 13 October 2007, there were only 47 local Igorot bloggers and 29 overseas Igorot bloggers included in Bill Bilig's blog roll. By February 2008, the number of local bloggers had increased to 62 while that of overseas bloggers to 32. At present, it is estimated that there are some 70 Philippine-based Igorot bloggers and 35 overseas bloggers.

There are more (13) female bloggers than (7) male bloggers. A breakdown of their profession and location is shown in the table below.

\begin{tabular}{|l|l|l|}
\hline Profession & Frequency & Location \\
\hline Accountant & 1 & Baguio City, Benguet -1 \\
\hline Bible translators/linguists & 4 & $\begin{array}{l}\text { Nueva Vizcaya }-3 \\
\text { Mountain Province }-1\end{array}$ \\
\hline Carer & 1 & UK - 1 \\
\hline Internet cafe owner & 1 & Ifugao - 1 \\
\hline Journalist/writer & 3 & Metro Manila-1; Baguio City - 2 \\
\hline Lawyer & 1 & Baguio City - 1 \\
\hline Photo-journalist & 1 & Kalinga - 1 \\
\hline Software developer & 2 & Metro Manila - 2 \\
\hline Student & 1 & Metro Manila - 1 \\
\hline Teacher & 4 & $\begin{array}{l}\text { Benguet - 1; Mountain Province - 2; } \\
\text { China - 1 }\end{array}$ \\
\hline Unknown & 1 & \\
\hline Total & $\mathbf{2 0}$ & \\
\hline
\end{tabular}

Table 1: Profession and Location of Igorot Bloggers

Most (11) of the bloggers work and live in the Cordillera region, three are in Nueva Vizcaya, four are in Metro Manila, while two are based overseas. One is a frequent traveller around Asia because of her church-related work as a bible translator, although she writes in her profile that she is in Bontoc, Mountain Province.

There are a wide range of themes that the bloggers write about, from personal reflections about relationships to foreign travels, entertainment news, Asian politics, experiences of overseas work and lessons in linguistics. At the same time, many of the bloggers proudly acknowledge their Igorot roots in their posts. They write about their hometowns and traditions, including socio-political issues affecting their provinces and the Cordillera region as a whole. 
Of the 20 blog sites I have monitored, all of them use English as the main medium of expression. Their facility with the language ranged from poor to excellent, although most may be categorized as having good English writing skills. Almost all bloggers write in English with a sprinkling of Filipino, the national language, and their own respective local (Kalanguya ang Kankana-ey, for instance) languages. The pervasiveness of the use of English among Igorot bloggers may be due to the strong American influence in the region, having been directly ruled by Americans for roughly 20 years (Finin 2005).

Arguably, identity construction is a form of social power (Grossberg 1996: 99; Jenkins 1996: 24 ). Grossberg writes that what is more crucial in understanding identity is the aspect of agency, rather than power. Thus, he makes a case for participation and access in order for people to exercise power in the process (1996: 99.). Consequently, he sees the possibility of changing history because 'agency constitutes strategic installations; these are the specific places and spaces that define particular forms of agency and empower particular populations' (ibid: 102). Indeed, the study of identity would be meaningless if the possibility of active participation by individuals in the making or unmaking of their socially constructed identities were absent in the discourse.

In studying online identities, several researchers hold the same findings that virtual identity needs to be grounded in both online and offline realities in order to capture the dynamic interaction taking place among users in cyberspace (Miller \& Slater 2000; Kennedy 2006; Zhao, et al. 2008; Forte 2006). With the plethora of Internet identity research going on at this time, what is evident is that each particular study addresses specific questions which are uniquely located within a particular space and time.

Mikhail Bakhtin's concepts of centripetal and centrifugal forces in relation to dialogized heteroglossia provide the framework for my study. Bakhtin believed that language should be studied in conjunction with its use in society, recognizing that it is a product of social interaction; 'language is always motivated and therefore framed within the struggle between different social groups' (Maybin 2001: 65). As a reflection of society, it is 'never unitary', but stratified into various socio-ideological languages and heteroglossia (Bakhtin 1981: 288; in Evans 2003: 272).

The concept of heteroglossia recognizes that language is not neutral and that people speak from particular positions (Bakhtin 1981: 290-294). Languages are 'specific world views, each characterized by its own objects, meanings and values' (ibid: 292). Part of the struggle for meaning can be found, according to Bakhtin, in centripetal and centrifugal forces in language use. Centripetal forces represent the authoritative view of religious, scientific, political and moral leaders. But language is stratified such that different groups in society speak with their own particular language brought about by centrifugal forces, otherwise termed as internally persuasive discourse' (ibid: 342, 271-272). These are 'expressed in everyday informal conversations and people's reflections of their own experience, within inner dialogues' (Maybin, 2001: 65), but are often taken for granted and unacknowledged (Bakhtin 1981: 342). Centrifugal and centripetal forces are constantly interacting and are always in a dialogue with each other, resulting in what Bakhtin describes as 'dialogized heteroglossia'. Indeed, 'The word in language is half someone else's' and it only becomes 'one's own' if a person appropriates it with his own intentions, accent and values (ibid: 293). 
Dialogism and the opposing concepts of centripetal and centrifugal forces may help put into perspective the tensions and struggles involved in the construction of Igorot identity through blogs. On the one hand, centripetal forces comprise centuries' old discourses about indigenous peoples as defined by colonial policies from the Spanish period until the time of the Americans. These policies and perspectives have been adopted to a large extent by Filipino leaders in dealing with Igorots (Finin 2005). In addition, writings by foreigners and lowland Filipinos and media representations have all contributed to the mainstream discourse about them. Up to the present time, there remains limited knowledge and understanding by the majority of Filipinos about the Igorots, as evidenced by media and communication research tackling aspects of representations of Igorots in soap operas (Zapata 2006) and even postcards (Torres 2005).

For their part, Igorots themselves have participated in the 'decentralizing, centrifugal forces' that challenge these discourses in the form of letters to the editor (Finin 2005) and discussions in Internet forums (Fong 2005). Over the decades, they have attempted to reevaluate the dominant discourses that have defined them as groups of people with a distinct way of life, via the platforms available to them. These attempts continue to this day, as can be gleaned from the blog posts of Igorots relating to ethnicity. These blogs, as sites for 'struggle among socio-linguistic points of view' (Bakhtin 1981: 271), seem to provide innovative ways for Igorots to reconstruct their identities and redefine discourses about themselves as a people.

\section{Case Study: Igorot Activism through Blogging}

On 14 January 2007, an American, Les Nash, uploaded a video on YouTube showing a statue of a man wearing a woven Igorot vest and loin-cloth urinating against a wall where a sign in Filipino says 'Bawal umihi dito'. Roughly translated, it means 'It is unlawful to urinate here'. The statue is part of other Igorot statues displayed outside a fine-dining restaurant in Baguio City in North Luzon. The video then shifts its focus onto another statue, this time of a security guard whistling at the Igorot man, the guard's left forefinger pointing at the man and his right hand holding his whistle. One month after the video was uploaded, Bill Bilig (http://igorotblogger.blogspot.com) wrote an angry post about the statue after finding it on YouTube. Bill Bilig, a play on the Kankana-ey word 'bilbilig' which means 'from the hinterlands', is the blogger identity of a 36-year-old male, Anglican, Kankana-ey from Mountain Province. He works for a church-based non-profit organization in the Philippines.

Bill wrote a total of six posts related to this issue. His first post, published on 21 February 2007, was 'Man Oh Man'. Portions of the text read as follows:

Boy am I really pissed. Yes, Igorot men pee just about anywhere. But all Filipino men of any ethnolinguistic background (whether Tagalog, Cebuano, Ilonggo, etc.) also pee just about anywhere. The owners could just as easily send their message by having a statue of a generic peeing man but they so emphatically decided to make him an Igorot.

Why? Because we are savages? Because we are a dirty, dirty people? Because we are uncivilized? Because we are uneducated and won't be able to read a sign which says, "No Urinating Here/Bawal Ang Umihi Dito/Maiparit ti Umisbo Ditoy". Because 
Igorots are so poor and won't have the money to go to that restaurant anyway? Essentially, that is what the restaurant owners are saying. Igorots are dirty, uncivilized, uneducated, poor people and only a security guard will be able to stop them from peeing in public. I'm sure the owners are very pleased with themselves whenever their masterpiece is photographed and videoed by its clients and curious tourists.

Clearly in these passages, Bill uses the same adjectives that non-Igorots have used in the past to describe Igorots in books, articles and films: by the Spaniards as 'pagan, savage and cruel' (Scott 1993: 49) or by the Americans as 'wild tribes' and 'inferior' (Finin 2005: 21, 26-27, 44). Thus the words 'savages', 'dirty', 'uncivilized', 'uneducated' and 'poor' are used prominently and in rapid succession. But this time, Bill uses these same words with indignation and defiance. While Bill takes on the unifying and centralizing voice of colonizers and non-Igorot authors, he speaks from the position of somebody who has been wronged. He further writes,

Our Lord Kabunian, if ever you read this blog, please send a bolt of lightning to this restaurant. But let's not wait for Kabunyan to do the work, he might have more important things to do like sending a bolt of lightning to those Anglican Primates who think that they are the second incarnation of Christ. Before we totally get distracted, does anyone out there know the name of this restaurant and its contact number? Can you share it with us? If possible, can we contact them and raise our concern? Can we call up Baguio politicians and raise this matter with them? Its election period and maybe they will be receptive to the concerns of the people.

Invoking the aid of Kabunian, the god of the Kankana-ey spirit world, Bill turns to his cultural roots for help. But he goes beyond praying to the spirits as he appeals for action and support from his readers.

Kayni, a female Igorot blogger based in Washington, DC, replied to this post by giving her own description of an Igorot.

I've heard of that restaurant before, but showing a statue of a urinating man is not so appropriate for a place to eat. They should take it out...hmm...maybe I'll take it out for them when I get to Baguio this year. Honestly, Igorots are well informed, intelligent, and respectable people, they don't deserve to be portrayed like that.

In response to a second post relating to the same issue, Chyt, a female Igorot university lecturer in Baguio City, writes,

Using an Igorot man to represent the 'urinating man' cannot be divorced from how we as an ethnic group have been regarded by the majority culture. We have for decades, if not centuries, been victims of ethnic prejudice...In St. Louis University where I teach, students from the lowlands are candid enough to admit that they always thought of Igorots as dirty people who rarely bathe and spit and urinate with wild abandon anywhere! I would ask them, what made you think so? The answer: 'Iyon po ang alam sa baba' (That is what we know in the lowlands). In this day and age, we Igorots are still on the defensive. 
These passages, which we may describe as part of what Bakhtin defines as centrifugal forces, show the active role of the author in identity construction. Both Kayni and Chyt share Bill's point of view that the statues show prejudice against Igorots. Bakhtin writes that individuals will 'sooner or later begin to liberate themselves from the authority of the other's discourse' (Bakhtin 1981: 348). Apparently, these blog posts show that Igorots continue to feel marginalized as an ethnic minority group by the existing discourses about them.

In his blog, Bill also posted an open letter to the Regional Director of the National Commission on Indigenous Peoples (NCIP), the key Philippine government agency tasked to promote the interests of indigenous peoples. Bill wrote that he 'felt insulted by this statue' and asked whether the office 'can do something about it'.

Within two weeks after Bill wrote his first post, Igorot bloggers and their offline network acted on Bill's post. With the help of some local officials, the insulting statue of the peeing Igorot man was removed by the management of the Barrio Fiesta restaurant. Reflecting on what took place, Bill writes:

This victory is a collective work. Although this blog takes credit for igniting the fire on this one, the fire could have easily died if others did not help. When I wondered about the identity of the restaurant, Wil and Nats immediately identified it and Kayni volunteered to go take it out. Then Bugan sent a copy of the letter we sent to NCIP officials to Bibaknets where the fire apparently got stronger. Then the Baguio folks (AYIP, Philian, Cheryl/Chyz, sorry I don't know everyone) did the more important work of bringing up the matter with the restaurant management as well as alerting a member of the media of what's happening. So all our efforts gelled to bring about the result we wanted.

The result of the efforts of Bill Bilig and other Igorot bloggers to remove the controversial statue became a news item in the Philippine Daily Inquirer, the country's leading national broadsheet. The article, entitled 'Statue of pissing Igorot removed amid blog protests', inaccurately said that it was 'Cordillerans based abroad' who protested about the statue (Cabreza 2007). Nonetheless, it highlighted the role of Igorot bloggers in the story (ibid).

As Miller and Slater (2000) pointed out, studying online identity needs to be grounded in offline reality as well. While they tackled the issue in their blogs, the Igorot bloggers nonetheless had to link with their offline networks to bring about the result they wanted. For this community of bloggers, issues regarding their ethnicity were not confined to their virtual worlds, but were very much a part of their lived experiences as well.

\section{Conclusion}

Igorot ethnic identity construction on the Internet is, to a large extent, rooted in the Igorot's struggle to provide a more accurate representation of who they are now, in these present times. It is an ongoing, dialogic process between dominant, centripetal forces and their own, smaller, centrifugal efforts, specifically blogging. Blogs appear to enable them to 'actively design their own meaning systems instead of passively consuming the meaning system of the prevailing social order' (Hamelink 1994: 142). They are actively engaging with the Internet and, to some extent, are achieving a measure of success. 


\section{References}

Abinales, P. (2000) Making Mindanao: Cotabato and Davao in the Formation of the Philippine Nation-State Quezon City: Ateneo de Manila University Press

Asian Development Bank (2002) Indigenous Peoples/Ethnic Minorities and Poverty Reduction: Philippines Manila, Philippines: Asian Development Bank

Bakhtin, M. (1981) The Dialogic Imagination Austin, Texas; London: University of Texas Press

Bausch, P. Haughey, M. \& Hourihan, M. (2002) We Blog: Publishing Online with Weblogs Indianapolis: Wiley Publishing Inc.

Braid, F. \& Tuazon, R. (1999) 'Communication Media in the Philippines: 1521-1986' Philippine Studies 47(3): 291-318

Cabreza, V. (2007) 'Statue of pissing Igorot removed amid blog protests' The Philippine Daily Inquirer, 8 March

Carroll, B. (2004) 'Culture Clash: Journalism and the Communal Ethos of the Blogosphere'in Gurak, L.J., S. Antonijevic, L. Johnson, C. Ratliff, \& J. Reyman (eds.) Into the Blogosphere: Rhetoric, Community, and Culture of Weblogs.

Available from:

http://blog.lib.umn.edu/blogosphere/culture_clash_journalism_and_the_communal_ethos_of the blogosphere.html

Celdran, D. (2002) 'The Philippines: SMS and Citizenship' Development Dialogue (1): 91103

Coronel, S. (2001) 'The Media, the Market and Democracy: The Case of the Philippines' The Public 8(2): 109-126

Coronel, S. (2005) Philippine Media: Free But Not Diverse in Journalism Asia Makati City, Philippines: Center for Media Freedom and Responsibility

Doronila, A. (1987) 'Media and Development' Development Research News V(5)

Finin, G. (2005) The Making of the Igorot Identity: Contours of Cordillera Consciousness Manila, Philippines: Ateneo de Manila University Press

Fong, J. (2005, unpub.) StarStruck: Minority Language and Construction of Ethnic Identity in Fan Blogs and Forum/Discussion Posts Paper Presented in Bangkok, Thailand

Forte, M. (2006) 'Amerindian@Caribbean: Internet Indigeneity in the Electronic Generation of Carib and Taino Identities' in Landzelius, K. (ed.) Native on the Net: Indigenous and Diasporic Peoples in the Virtual Age London; New York, NY: Routledge

Gordon, R.G. Grimes, B.F. \& Summer Institute of Linguistics (eds.) (2005) Ethnologue: Languages of the World, Fifteenth edition Dallas, Tex.: SIL International 
Grossberg, L. (1996) 'Identity and Cultural Studies: Is That All There Is?' Hall, S. and P. du Gay (eds.) Questions of Cultural Identity London; Thousand Oaks, CA: Sage

Hamelink, C. (1994) Politics of World Communication: A Human Rights Perspective London; Thousand Oaks, CA: Sage

Hirtz, F. (2003) 'It Takes Modern Means to be Traditional: On Recognizing Indigenous Cultural Communities in the Philippines' Development and Change 34(5): 887-914

Hofilena, C. (2004) News for Sale: The Corruption and Commercialization of the Philippine Media Quezon City, Philippines: Philippine Center for Investigative Journalism

Jenkins, R. (1996) Social Identity London; New York, NY: Routledge

Khan, R. (2005) 'A Manila-centric Press' Pluralism in the News Room, Journalism

Asia Series (Manila: Center for Media Freedom and Responsibility, May 2005): 30-31

Khan, R. (2006) 'Blogging, New Journalism?’ Philippine Journalism Review

Kennedy, H. (2006) 'Beyond Anonymity, or Future Directions for Internet Identity Research' New Media and Society 8(6): 859-876

Maybin, J. (2001) 'Language, Struggle and Voice: The Bakhtin/Volosinov Writings' in Wetherell, M. Taylor, S. \& Yates, S. (eds.) Discourse Theory and Practice: A Reader London; Thousand Oaks, CA: Sage

Mendes, S. Alampay, E. Soriano, E. \& Soriano, C. (2007) The Innovative Use of Mobile Applications in the Philippines - Lessons for Africa Stockholm: SIDA

Miller, D. \& Slater, D. (2000) The Internet: An Ethnographic Approach Oxford: Berg

Pineda-Pineda-Ofreneo, R. (1984) The Manipulated Press: A History of Philippine Journalism since 1945 Metro Manila, Philippines: Cacho Hermanos

Rabia, S. (forthcoming MA Thesis) The Igorot in the World Wide Web: Exploring the Igorot Ethnic Identity through the Communicative Act of Blogging Quezon City: University of the Philippines-Diliman

Rafael, V. (2003) 'The Cell Phone and the Crowd: Messianic Politics in the Contemporary Philippines' Public Culture 15(3): 399-425

Rimban, Luz (1999) 'That's Not News, That's Entertainment' i-Magazine 5(4)

Scott, W.H. (1993) Of Igorots and Independence: Two Essays Baguio City, Philippines: ERA

Sy, P. (2001) 'Barangays of IT: Filipinizing Mediated Communication and Digital Power' New Media and Society 3(3): 296-312 
Torres, A.C. (2006) 'Igorot Representation in Cordillera Picture Postcards' Plaridel 3(1): $123-146$

Woodly, D. (2007) 'New Competencies in Democratic Communication? Blogs, AgendaSetting and Political Participation' Public Choice 134(1-2): 109-15

Zapata, D. (2006) (MA Thesis) Televising Ethnicity: (Re)Constructing Igorot Identity in Television Quezon City: University of the Philippines-Diliman

Zhao, S. Grasmuck, S. \& Martin, J. (2008) 'Identity Construction on Facebook: Digital Empowerment in Anchored Relationships' Computers in Human Behavior. 24(5): 1816-1836

\section{Web sources}

Astrologo, Candido Jr. (2006) ICT Statistics: Show Me the Data. Available from: www.nscb.gov.ph/headlines/StatsSpeak/081406_rav_cja_ict.asp [Accessed 26 November 2007]

National Commission on Indigenous Peoples (2003) Indigenous Peoples of the Philippines. Available from: www.ncip.gov.ph/resourcesdetail.php?id=1 [Accessed 11 July 2008]

National Statistical Coordination Board (2006) Annual Per Capita Poverty Thresholds, Poverty Incidence and Magnitude of Poor Families: 2000, 2003 and 2006.

Available from: www.nscb.gov.ph/poverty/2006_05mar08/table_1.asp [Accessed 11 July 2008]

National Statistical Coordination Board (date?) Population of the Philippines Census Years 1799 to 2007. Available from: www.nscb.gov.ph/secstat/d_popn.asp [Accessed 28 July 2008]

National Statistics Office (2003) The 2003 Functional Literacy, Education and Mass Media Survey. Available from: $\quad$ www.census.gov.ph/CARAGA/HTML/FLEMMS.htm [Accessed 15 August 2008]

Macansantos, F. (2004) Sinai Hamada and the Power of Sympathy. Available from: www.ncca.gov.ph/about-culture-and-arts/articles-on-c-n-a/article.php?i=34\&subcat=13 [Accessed 26 August 2008]

Olarte, A. (2005) Journalists as Bloggers: The Forum. Available from: www.pcij.org/blog/?p=452 [Accessed 17 August 2008]

Ordoñez, E. (2007) ‘Aves de Rapina’ revisited. The Manila Times [internet] 29 September. Available from: www.manilatimes.net/national/2007/sept/29/yehey/opinion/20070929opi2.html [Accessed 19 August 2008]

Pabico, A. (2005) The Pinoy Blogosphere. Presented during the Journalists as Bloggers: The Forum, held on 22 October 2005, Linden Suites, Pasig City, Philippines. Available from: www.pcij.org/blog/?p=452 [Accessed 17 August 2008] 